\title{
Epidermal Growth Factor in Mouse Ocular Tissue: Effects of Thyroxine and Exogenous Epidermal Growth Factor
}

\author{
J. LAKSHMANAN, J. PERHEENTUPA, S. B. HOATH, H. KIM, A. GRUTERS, C. ODELL, AND \\ D. A. FISHER \\ Perinatal Research Laboratories, Harbor-UCLA Medical Center, UCLA School of Medicine, \\ Torrance, California 90509
}

\begin{abstract}
Using a specific and sensitive epidermal growth factor (EGF) radioimmunoassay, we identified radioimmunoasayable EGF both in developing and adult mouse ocular tissues. In neonatal animals ocular EGF concentrations increase during the first 4-9 days and then decline between 9 and 15 days. Thyroxine (T4) administration $(0.4 \mu \mathrm{g} / \mathrm{g}$ body weight/day from day 0$)$ increased local EGF concentrations in eye and skin of 7-day-old neonatal mouse pups. However, this treatment did not affect submandibular gland EGF concentrations during the 1st wk of life. Both EGF and T4 are known to accelerate eye opening in the neonatal mouse. Exogenous EGF administration ( $2 \mu \mathrm{g} / \mathrm{g}$ body weight/day) during the first 8 days of life elicited precocious eyelid opening as expected but did not alter the serum T4 concentration, suggesting that EGF does not mediate eye opening by $\mathbf{T} 4$ dependent mechanism(s). Tissue EGF measurements revealed that the exogenous EGF was localized in skin and eye; however, other tissues including lung, liver, heart and submandibular gland also contained exogenous EGF. Kidney-EGF concentrations did not rise while brain-EGF levels were significantly decreased after exogenous EGF, suggesting that different EGF uptake and regulatory mechanism(s) exist in different tissues during the neonatal period. $\mathrm{T} 4$ administration $(0.4$ $\mu \mathrm{g} / \mathrm{g}$ body weight/day) for 10 days to adult mice also increased ocular-EGF concentrations. However, this increase was abolished by sialoadenectomy, suggesting in contrast to the newborn, that submandibular gland is an important source of ocular-EGF in adult mice. These studies indicate that ocular EGF in the mouse is thyroxine responsive only during the neonatal period. (Pediatr Res 19: 315-319, 1985)
\end{abstract}

\section{Abbreviations}

T4, thyroxine

EGF, epidermal growth factor

BW, body weight

SMG, submandibular glands

RIA, radioimmunoassay

T3, triiodothyronine

Received June 13, 1984; accepted November 8, 1984.

Requests for reprints should be addressed to Dr. J. Lakshmanan, Harbor-UCLA Medical Center, Bldg-A-17, 1000 West Carson Street, Torrance, CA 90509.

This research was supported by NIH Grants HD-04270(DAF) and NS$17431 \mathrm{~A}(\mathrm{JL})$.
Thyroid hormones have been shown to accelerate maturation of ocular tissues in both mammalian and submammalian species. In anuram larvae local T4-cholesterol implantation stimulates the development of eyelids, formation of nictitating membranes, fusion of cornea, growth of extrinsic muscles, and bulging of the eyes (1). T4 stimulates the conversion of porphyropsin to rhodopsin both in metamorphosing tadpoles (2) and in rainbow trout (3). The photo pigment conversion by $\mathrm{T} 4$ also appears to be a local effect since monocular implantation of T4-impregnated pellets causes a greater increase in rhodopsin levels in the treated than in the contralateral eye (2).

Thyroid hormones also stimulate cell proliferation in lens epithelium of both intact (4) and hypophysectomized adult frogs (5). In chick embryos thyroid hormones accelerate the development of corneal epithelium and endothelium, the two cell layers essential for the maintenance of corneal transparency (6). Conversely thiouracil, an antithyroid agent, has been shown to delay corneal histogenesis. Similar opposing effects of thyroid hormones and antithyroid drugs have been demonstrated on corneal dehydration (7) and total corneal thickness, as well as changes in electrolyte content (8). In rat embryos, congenital eye defects ranging from excessive retinal fold formation to complete absence of the lens have been reported following partial thyroidectomy of the mother before prgnancy (9). In neonatal rodents, administration of thyroid hormones accelerates eyelid opening, while neonatal hypothyroidism signficantly delays this developmental process $(10,11)$.

EGF, a polypeptide with mitogenic effects on a variety of epithelial cells, has been demonstrated to evoke precocious eyelid opening in newborn rats and mice (12). In vivo and in vitro studies suggest that EGF may function as a mitogenic agent for both corneal epithelial $(13,14)$ and endothelial cells $(15,16)$. EGF receptors have been identified in lens epithelial cells (17) and mitogenic responses of these cells have been observed in response to EGF in vitro $(18,19)$. Recently, EGF also has been shown to evoke angiogenic effects in the avascular corneal stroma in vivo (20). Hamburgh et al. (21) have shown that EGF administered systemically will correct the developmental delay of eyelid opening in hypothyroid rats. Recently we reported that thyroid hormone administration increases EGF concentrations in neonatal mouse skin (22).

To determine whether the action of thyroid hormones on eyelid opening and eye maturation might be mediated by local alterations in EGF concentrations, T4 was administered to newborn mice and changes in ocular EGF concentrations were assessed by a specific EGF-RIA. The results suggest that thyroid hormones modulate local EGF concentrations in ocular tissues 
during development. Exogenous administration of EGF also increased ocular EGF concentrations suggesting the existence of an EGF uptake mechanism in ocular tissues during the neonatal period. Studies extended to adult mice suggest that the period of ocular tissue EGF sensitivity to thyroid hormones is confined to the neonatal period.

\section{MATERIALS AND METHODS}

Animals and treatments. Time dated, pregnant Swiss-Webster mice were purchased from Simonsen Laboratories, Gilroy, CA. The mice were housed individually in light controlled rooms and allowed free access to food and water. The day of birth was considered to be day 0 . Eight pups per mother were maintained for eye-EGF ontogeny studies; in these studies the pups were sacrificed on days $0,3,6,9,12$, and 15 of postnatal life.

For T4 response studies, newborn mice were injected subcutaneously with daily doses of $0.4 \mu \mathrm{g} \mathrm{T} 4 / \mathrm{g} \mathrm{BW}$ in $5 \mu 1$ volume of $0.001 \mathrm{~N} \mathrm{NaOH}$. Control animals were injected with similar volumes of vehicle. Both control and experimental pups were given injections from birth (day 0 ) to day 5 and were sacrificed on day 6 . This time period was chosen since preliminary studies revealed this dose and treatment schedule were sufficient to induce both precocious tooth eruption and eyelid opening. For EGF response studies, newborn pups were injected daily subcutaneously with $2 \mu \mathrm{g} \mathrm{EGF/g} \mathrm{BW} \mathrm{dissolved} \mathrm{in} \mathrm{saline;} \mathrm{littermates}$ received equivalent volumes of saline. Injections were commenced within $12 \mathrm{~h}$ of birth and repeated at the same time each day until day 8 . Animals were sacrificed on day 9 (the day of eyelid opening in EGF-treated pups) through acceleration of T4 production.

For studies in adult female mice, animals were purchased from the supplier 5-7 days prior to treatment and housed in groups of 3-4 animals per cage. All animals were treated with T4 (0.4 $\mu \mathrm{g} / \mathrm{g} \mathrm{BW} /$ day) or vehicle for a period of 10 days and sacrificed $24 \mathrm{~h}$ after the last injection. A total of 18 animals per group were used. Blood was collected from the inferior vena cava and pooled; serum samples were used for hormone measurements.

Sialoadenectomy studies were conducted in adult female Swiss-Webster mice weighing 30-35 g. Animals were anesthetized with $0.1 \mathrm{mg} / \mathrm{g} \mathrm{BW}$ sodium pentobarbital (Trico Pharmaceutical Co., San Carlos, CA) given as a $1 \%$ solution in saline. Submandibular glands were excised under aseptic conditions and the skin sutured. Streptomycin sulphate was applied locally to avoid postoperative infection. Following surgery, animals were housed in groups of three. Thirty days after sialoadenectomy the mice were treated with T4 $(0.4 \mu \mathrm{g} / \mathrm{g} \mathrm{BW} /$ day $)$ or vehicle for a period of 10 days. Mice were sacrificed $24 \mathrm{~h}$ after the last injection and blood was collected from the inferior vena cava for serum hormone measurements.

Preparation of Tissue Extracts. In all groups eyes were removed, trimmed of connective tissue, and pooled prior to freezing on dry ice. For studies involving neonatal pups, 32-40 eyes were pooled per tube, whereas in adult animals 6-12 eyes were used per tube. Both SMG and dorsal skin were removed and frozen on dry ice before storage at $-20^{\circ} \mathrm{C}$. SMG tissues were pooled in neonatal groups (eight glands per tube), whereas glands removed from adult animals were processed individually. Tissues were routinely processed within $48 \mathrm{~h}$ after removal. Both SMG and eyeballs were homogenized in phosphate-buffered saline (homogenizing buffer), $\mathrm{pH} 7.2$, at $4^{\circ} \mathrm{C}$ using a glass Teflon homogenizer. Whole dorsal skin homogenate were prepared using a Tekmar Tissuemizer as described earlier (22). All homogenates were centrifuged at $25,000 \times g$ for $30 \mathrm{~min}$ at $4^{\circ} \mathrm{C}$ and supernatants were used both for protein determination (23) and for EGF-RIA.

$E G F-R I A$ and Recovery Studies. EGF was measured by double antibody RIA as previously described (22). Standard curves were prepared in triplicate at nine dilutions and samples were assayed in triplicate at two dilutions. Parallelism of $\left[{ }^{125} \mathrm{I}\right] \mathrm{EGF}$ displace- ment by dilutions of eyeball tissue homogenate supernatant and standard EGF was assessed in thyroxine treated and control neonatal and adult mice. Recovery studies were performed by adding varying amounts of standard EGF to $100 \mu \mathrm{l}$ of eye homogenate supernatants from young and adult mice. The measured EGF per tube was compared to the amount expected. Percentage recoveries were calculated from quintuplicate specimens. Mean recovery was $108 \pm 4 \%$ (mean \pm SEM).

Serum thyroid hormone measurements. Serum T4 and T3 concentations were measured as described earlier (22). $\left[{ }^{125} \mathrm{I}\right]$ labeled T4 and T3 were purchased from Nichols Institute (San Juan Capistrano, CA).

Purification of EGF. EGF was isolated as described by Savage and Cohen (24). The final fraction was characterized as a single band by polyacrylamide gel electrophoresis and manifested an apparent molecular weight of 6000 as described previously (22). The bioassy for EGF in newborn mice was performed according to the method of Cohen (12). Briefly mice were treated (subcutaneously) from birth, either with saline or EGF (1 or $2 \mu \mathrm{g} / 1.5 \mathrm{~g}$ $\mathrm{BW} /$ day); a total of six pups for each dose was employed. Both higher and lower doses elicited eyelid opening on days 8 and 9 , respectively. Saline-treated pups opened their eyelids on day 14 . These results are similar to those reported by Cohen (12).

Statistical analyses. Statistical analysis of the data was conducted using Student's $t$ test; the level of significance was taken as $p<0.05$ unless otherwise specified.

\section{RESULTS}

RIA of EGF in eye homogenates and developmental changes. Figure $1 A$ illustrates the displacement curves of purified mouse EGF and eye homogenate supernatant dilutions in the EGFRIA. Displacment curves of $\left[{ }^{125} I\right] E G F$ from antibody were parallel for standard EGF and for serial dilutions of eye extracts prepared from neonatal and adult female mice with and without T4 treatment. This indicates the presence of EGF-like immunoreactive material both in neonatal and in adult ocular tissues.

EGF-RIA measurements also were conducted in eye tissue homogenate supernatants prepared from neonatal animals during various stages of development. Figure $1 B$ shows the ontogenetic profile of eye-EGF content (pg EGF/pair of eyes) as a function of increasing postnatal age. Between 4-9 days of age there was a progressive increase in ocular EGF concentration; the mean EGF concentration increased 7- to 8-fold (from 14$106 \mathrm{pg} /$ pair of eyes) during this 5-day period. A marked reduction in eye EGF concentration was observed between 9 and 15 days. The mean EGF concentration on day 15 approximates $25 \%$ of the level observed on day 9 of neonatal life.

Influence of T4 on EGF concentrations in eye, skin, and SMG tissue of neonatal mice. Serum concentrations of T4 and T3 in mice receiving T4 $(0.4 \mu \mathrm{g} / \mathrm{g} \mathrm{BW} /$ day during the first 6 days) were significantly elevated compared to control mice. (Control versus T4-treated animals: T4 $2.2 \pm 0.2$ versus $15.0 \pm 1.9 \mu \mathrm{g} / \mathrm{dl}, p<$ 0.0001 ; T3 $40 \pm 3.5$ versus $71 \pm 7.0 \mathrm{ng} / \mathrm{dl}, p<0.005)$. No significant differences were noted in mean body weights of control and T4 treated animals $(3.44 \pm 0.07$ versus $3.58 \pm 0.09$ $\mathrm{g}$, respectively, $p>0.05$ ). T4 treatment increased mean EGF concentration both in skin and eye (Fig. $2 A$ ); the mean SMGEGF concentration of T4-treated animals was not significantly different from that of controls.

Effects of EGF administration on serum T4 and tissue EGF concentration in neonatal mice. Administration of EGF, $2 \mu \mathrm{g} / \mathrm{g}$ $\mathrm{BW} /$ day, did not affect the mean body weight or mean serum T4 levels (Table 1), but the EGF-treated animals exhibited early eyelid opening on day 9 . There was no change in (wet) organ weights (expressed as \% BW) of the EGF-treated animals relative to controls. Ther results of tissue EGF concentrations are shown in Figure 3; EGF was expressed relative to $\mathrm{mg}$ of tissue protein. Significant increments in EGF were detectable in all tissues studied. The tissue EGF concentrations in control animals varied 
in decreasing order as follows: brain, kidney, skin, lung, eye, SMG, heart, and liver. EGF injection produced significant increases in EGF concentrations in skin, eye, lung, liver, SMG, and heart tissues relative to control animals. Mean kidney EGF concentrations were not altered and mean brain EGF concentration after EGF treatment was significantly decreased (Fig. 3).

Effect of T4 administration with and without sialodenectomy in adult mice. Administration of T4 $(0.4 \mu \mathrm{g} / \mathrm{g} \mathrm{BW} /$ day $)$ to adult female mice for 10 days increased serum T4 (control versus T4treated animals: $4.4 \pm 0.6$ versus $17.8 \pm 1.8 \mu \mathrm{g} / \mathrm{dl}, p<0.01)$ and T3 concentrations $(40 \pm 10.3$ versus $592 \pm 159, \mathrm{ng} / \mathrm{dl}, p<0.01)$.
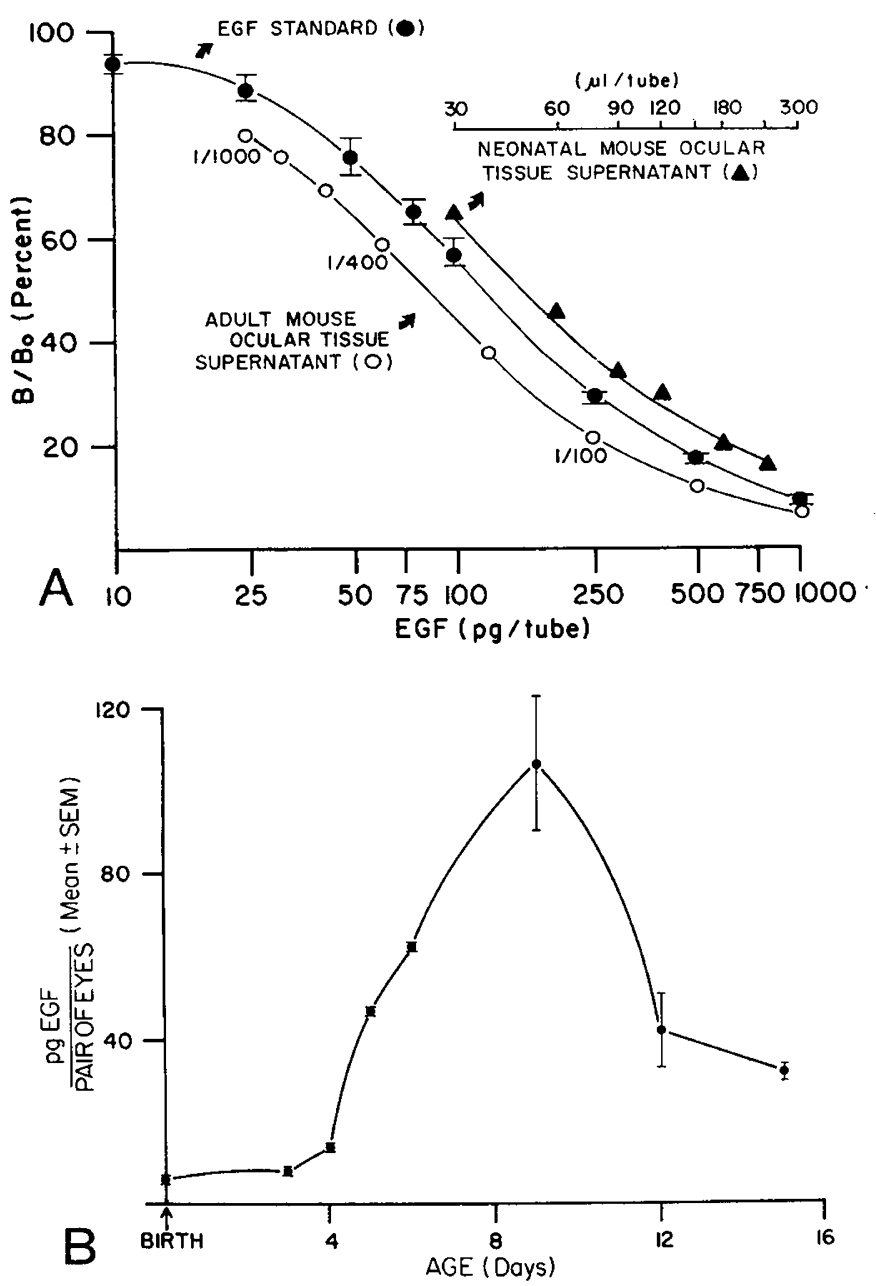

Fig. 1. $A$, radioimmunoassay for mouse SMG-EGF (๑). Parallel displacement was observed for serial dilutions of ocular tissue supernatant $(O)$, adult mouse and $(\boldsymbol{\Delta})$, neonatal mouse. $B$, developmental profile of ocular-EGF content in neonatal mice. Each point represents the mean \pm SEM of three or four individual determinations. See "Materials and Methods" for details of pooling of tissue specimens.
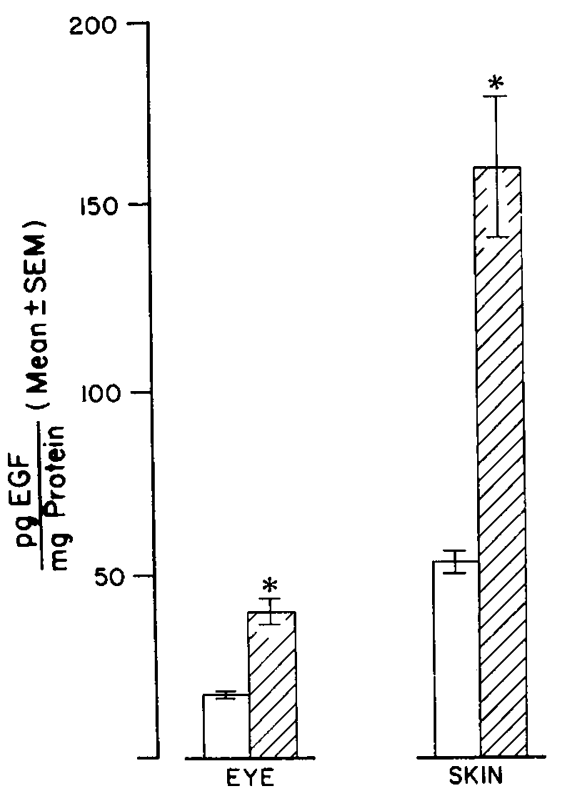

CONTROL

THYROXINE

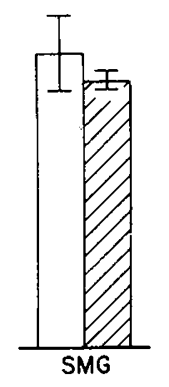

Fig. 2. Effect of T4 administration on EGF levels in eye, skin, and SMG. Newborn mice received daily injections of thyroxine or vehicle from day 0 to 5 and were sacrificed on day 6 .

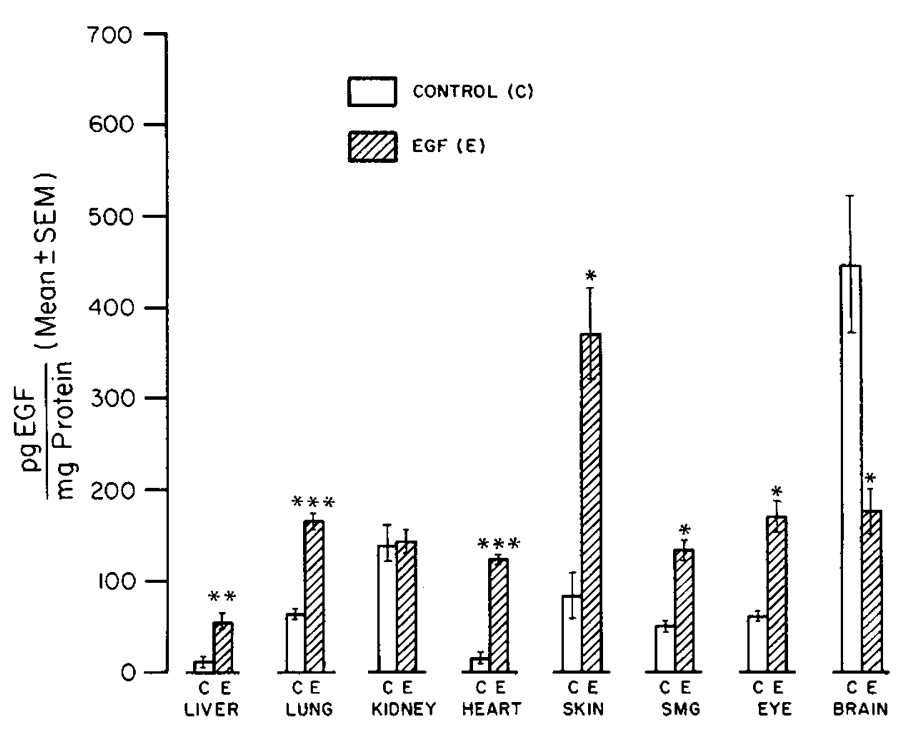

Fig. 3. Effect of EGF administration on tissue EGF concentrations in neonatal mice. Newborn pups were injected daily with EGF $(2 \mu \mathrm{g} / \mathrm{g}$ $\mathrm{BW} /$ day) or saline from day 0 to 8 . Animals were sacrificed on day 9 and tissue EGF was quantified by RIA as described in "Materials and Methods." Each bar represents mean \pm SEM of three or four individual determinations. No statistically significant differences were noted in kidney-EGF concentrations for EGF-treated compared to control pups. ${ }^{*} p<0.01 ;{ }^{* *} p<0.005 ;{ }^{* * *} p<0.001$.

Table 1. Effect of exogeneous EGF administration in neonatal mice*

\begin{tabular}{|c|c|c|c|c|c|c|c|c|c|c|c|}
\hline \multirow[b]{2}{*}{ Treatment } & \multirow[b]{2}{*}{ No. of animals } & \multicolumn{2}{|c|}{ Body wt } & \multirow{2}{*}{$\begin{array}{c}\text { Serum T4 } \\
(\mu \mathrm{g} / \mathrm{dl})\end{array}$} & \multicolumn{7}{|c|}{ Organ wt $(\mathrm{g} / 100 \mathrm{~g} \mathrm{BW})$} \\
\hline & & Day 0 & Day 9 & & Brain & Kidney & Lung & Eye & SMG & Heart & Liver \\
\hline Saline & 48 & $\begin{array}{c}1.51 \\
\pm .035\end{array}$ & $\begin{array}{r}6.15 \\
\pm .09\end{array}$ & $\begin{array}{r}8.1 \\
\pm .29\end{array}$ & $\begin{array}{r}5.23 \\
\pm .29\end{array}$ & $\begin{array}{l}1.32 \\
\pm .07\end{array}$ & $\begin{array}{l}1.99 \\
\pm .11\end{array}$ & $\begin{array}{l}0.45 \\
\pm .01\end{array}$ & $\begin{array}{r}0.59 \\
\pm .02\end{array}$ & $\begin{array}{l}0.59 \\
\pm .02\end{array}$ & $\begin{array}{r}3.36 \\
\pm .07\end{array}$ \\
\hline EGF & 32 & $\begin{array}{c}1.57 \\
\pm .034 \\
\text { NS }\end{array}$ & $\begin{array}{c}5.90 \\
\pm .13 \\
\text { NS }\end{array}$ & $\begin{array}{c}7.6 \\
\pm .022 \\
\text { NS }\end{array}$ & $\begin{array}{c}5.40 \\
\pm .16 \\
\text { NS }\end{array}$ & $\begin{array}{c}1.25 \\
\pm .07 \\
\text { NS }\end{array}$ & $\begin{array}{c}1.85 \\
\pm .14 \\
\text { NS }\end{array}$ & $\begin{array}{c}0.43 \\
\pm .02 \\
\text { NS }\end{array}$ & $\begin{array}{c}0.55 \\
\pm .03 \\
\text { NS }\end{array}$ & $\begin{array}{c}0.61 \\
\pm .01 \\
\text { NS }\end{array}$ & $\begin{array}{c}3.25 \\
\pm .08 \\
\text { NS }\end{array}$ \\
\hline
\end{tabular}

* Newborn pups received either EGF ( $2 \mu \mathrm{g} / \mathrm{g} \mathrm{BW} /$ day) or saline from day 0 to day 8 and were sacrificed on day 9 . Data are presented as mean \pm SEM. Tissue weights were registered either singly (brain, SMG, heart, and liver) or in pairs (lung, kidney, and eye). 
Hormone treatment did not affect mean body weight (body weight of T4-treated animals before and after hormone treatment: $35.5 \pm 0.6$ and $37.8 \pm 0.8 \mathrm{~g}, p>0.05$ ). After 10 days treatment, mean EGF concentrations in SMG and eye tissues had increased to 318 and $1125 \%$ of control values, respectively $(p<0.001)$ (Fig. 4). The administration also increased skin EGF concentration as previously reported (25). The results of sialoadenectomy on tissue EGF concentration responses to T4 treatment of adult female mice are shown in Table 2. The T4 treatment produced the expected increase in serum $\mathrm{T} 4$ and $\mathrm{T} 3$ levels without affecting mean body weight. However, in contrast to previous experiments, sialoadenectomy abolished the T4 evoked increase in EGF in the eye tissue.

\section{DISCUSSION}

As already discussed, thyroid hormones have been shown to accelerate development of the eye. Although malformations of the eye are not consistently observed following the administration of antithyroid substances, a wide range of intraocular abnormalities in several species have been demonstrated in response to

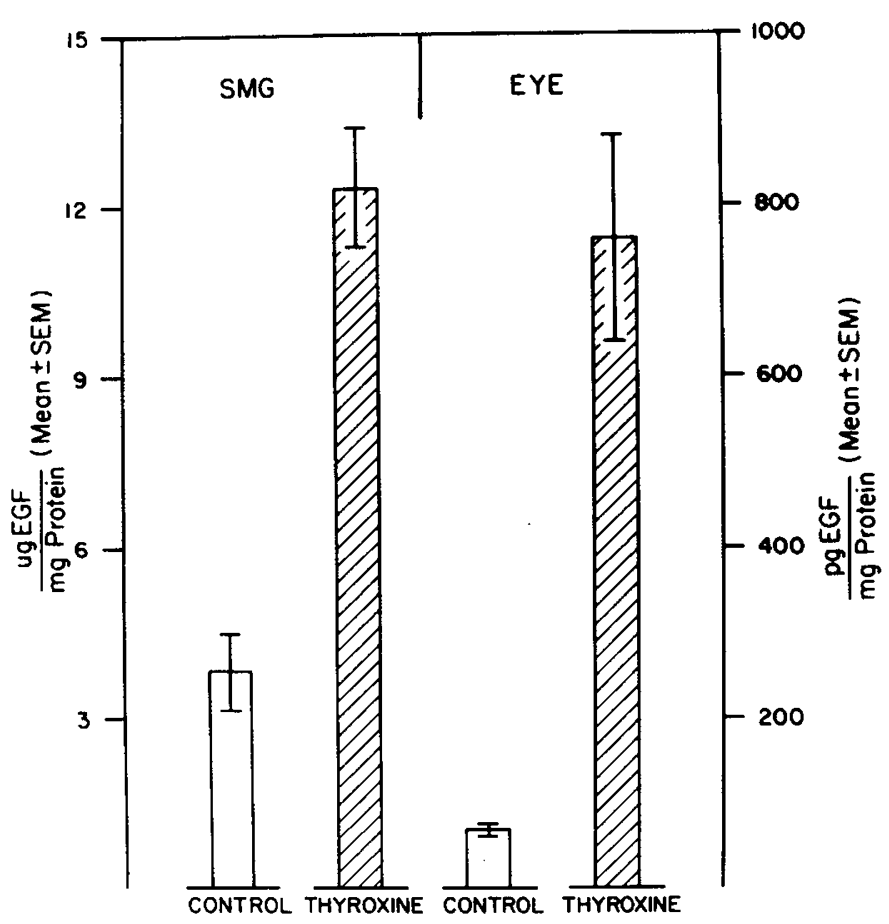

Fig. 4. Effect of exogenous T4 on SMG and eye EGF concentrations in adult mice. Adult female mice were injected with $\mathrm{T} 4$ or vehicle for 10 days and tissue EGF contents were measured as described in "Materials and Methods." Results represent the mean \pm SEM of three independent determinations. ${ }^{*} p<0.001$. abnormalities of thyroid function (hypo and hyperthyroidism). Both morphological and biochemical parameters, for neural retina $(9)$ to corneal cells $(6,26)$, have been reported to be sensitive to changes in thyroid hormone status. In contrast, there is only limited information at present to suggest that EGF influences ocular morphogenesis. EGF is known to accelerate eyelid opening in both euthyroid (12) and hypothyroid neonatal rodents (21) and there is accumulating evidence to suggest that both corneal epithelium and endothelium represent target tissues of EGF (27). The mitogenic responses of these cells, taken together with the evidence for the existence of functional EGF receptors in lens epithelium $(18,19)$, support this view. However, to date, there has been no report of an adverse effect of EGF antiserum on the developing eye.

We previously proposed the hypothesis (28) that EGF may be mediating selected maturational effects of thyroid hormones. To test this hypothesis we measured EGF in developing eye tissue with and without T4 administration. Our results document, for the first time, the existence of EGF in the developing eye. Though the origin and site(s) of EGF localization in the eye have not been resolved by the present studies, the observed rapid increase and then decline in EGF concentration in neonatal mouse eye tissue support the view that this growth factor has a role in maturation of the eye during this critical period. The eye opening effect of T4 is reported to be due to growth of the eye and resulting exophthalmos (29), whereas EGF is reported to have a direct effect on keratinization of the eyelid skin (30).

The observation in the present study that $\mathrm{T} 4$ increases eye EGF concentration would support the hypothesis that T4 mediates the orderly events of eye maturation through EGF effects on both skin and eye tissues. The dose of T4 utilized is in the pharmacological range (e.g. $0.4 \mu \mathrm{g} / \mathrm{g} \mathrm{BW}$ versus a physiological dose of 0.02 to $0.04 \mu \mathrm{g} / \mathrm{g} \mathrm{BW}$ ), and despite this we observed that T4 did not increase SMG EGF in the neonatal animal, whereas a marked SMG-EGF response to T4 was observed in the adult. This suggests that T4 may stimulate local EGF synthesis or EGF receptor binding in the neonatal eye. Whether the lack of EGF responsiveness in neonatal SMG, in contrast to skin and eye tissues, is secondary to absence of specific hormone receptors or postreceptor mechanism(s) requires further investigation.

EGF has been suggested to exert a TRH-like effect in the CNS (31). In addition, high concentrations of EGF have been identified in human thyroid glands (32), and EGF has been shown to be a potent mitogen for sheep thyroid cells in tissue culture (33). Thus, to exclude an effect of EGF on thyroid metabolism, we investigated the effect of EGF on serum T4 levels in developing mice. The lack of an EGF effect on serum T4 does not rule out an effect of EGF on hypothalamic-pituitary thyroid maturation or function, but does suggest that the effect of EGF on eyelid opening is not mediated via an increase in T4 secretion. The observed increase in EGF content both in skin and eye suggests that enhanced epidermal keratinization of supraocular skin and ocular growth together may contribute to the T4 mediated early eyelid opening process. However, the nature of cellular and

Table 2. Effect of exogenous T4 administration on eye-EGF in sialoadectomized adult female mice

\begin{tabular}{lcccccc}
\hline & \multicolumn{2}{c}{ Body wt $(\mathrm{g})$} & & \multicolumn{2}{c}{ Serum iodothyronines } \\
\cline { 2 - 3 } Treatment & Initial & Final & & $\begin{array}{c}\mathrm{T} 4 \\
(\mu \mathrm{g} / \mathrm{dl})\end{array}$ & $\begin{array}{c}\mathrm{T} 3 \\
(\mathrm{ng} / \mathrm{dl})\end{array}$ & $\begin{array}{c}\text { Eye-EGF concentrations } \\
(\mathrm{pg} / \mathrm{mg} \mathrm{protein})\end{array}$ \\
\hline Control & $30.8 \pm 0.4$ & $32.4 \pm 0.2$ & & $6.2 \pm 1.1$ & $50 \pm 11$ & $50 \pm 29$ \\
Thyroxine & $33.9 \pm 0.6$ & $37.2 \pm 1.0$ & & $15.4 \pm 4.2^{*}$ & $486 \pm 144 \dagger$ & $26 \pm 13$ \\
& $\mathrm{NS}$ & $\mathrm{NS}$ & & & NS \\
\hline
\end{tabular}

Thirty days after surgery mice were treated daily with $\mathrm{T} 4(0.4 \mu \mathrm{g} / \mathrm{g} \mathrm{BW} /$ day $)$ or vehicle for 10 days. Results are expressed as mean \pm SEM. See "Materials and Methods" for other details.

$\dagger p<0.01$.

$\dagger p<0.001$

$\ddagger p<0.05$. 
biochemical mechanism(s) that underlie this process remains obscure.

The effect of EGF on eye opening in neonatal mice indicates that the EGF preparation used in this study had very similar biopotency as reported by others $(12,34,35)$. However, we did not observe a decrease in body weight in response to EGF as observed by other investigators (34-36). The reason for this is not clear. Similarly, EGF administration did not affect organ weights. In studies conducted in newborn rats using a similar dose and duration of EGF administration, Heimberg et al. (36) observed an increased liver/BW ratio thought to be secondary to increased hepatic triglyceride accumulation. These results suggest the possibility of a species specific organ response to EGF.

The present results of measurements of tissue EGF levels following EGF administration indicate a differential distribution in various tissues. Based on the relative EGF distribution the tissues could be classified into three categories: tissues with increased (skin, eye, heart, lung, SMG, and liver), decreased (brain), and unchanged (kidney) EGF levels. Whether these variations in tissue EGF distribution represent differences in rate of EGF uptake, binding, or degradation needs to be studied. Many cell types and membrane preparations of primary cells and whole organs have been shown to contain EGF receptor systems (37). Evidence for the existence of EGF induced down regulation of EGF receptor systems in embryonic tissues (38) and specific in vivo uptake in skin and eyes of adult animals (39) suggest that neonatal animals are likely to possess similar receptor mechanisms.

The absence of $\mathrm{T} 4$ responsiveness of EGF concentrations in adult eye tissues of sialectomized mice suggests that SMG is the source for the increased eye EGF levels observed in nonsialectomized adult mice after T4 treatment. In the present study, we did not investigate whether T4 caused release of EGF from SMG. Both $\alpha$-adrenergic agonists (40) and aggressive behavior (41) have been reported to cause release of EGF from adult SMG. Experiments are in progress to determine whether T4 causes of SMG-EGF in addition to its effect on EGF synthesis in SMG. The absence of $\mathrm{T} 4$ responsiveness of eye EGF in sialoadenectomized adult mice contrasts with the effect of T4 in neonatal animals in which ocular EGF levels increased in the absence of an increase in SMG-EGF. Another extrasalivary source of EGF is possible in the neonatal period; this also is under investigation.

The thyroid hormone-mediated increase in skin and eye EGF in the neonatal period may represent an effect of T4 on tissue EGF synthesis, tissue EGF uptake/binding, or EGF degradation. Further study is necessary to assess these possibilities. Also, it is not clear whether EGF and T4 elicit eyelid opening by similar mechanisms. The identification and study of specific biochemical responses in various intraocular tissues may provide a model(s) to study whether thyroid hormones mediate growth responses through specific growth factors.

\section{REFERENCES}

1. Kaltenbach JC 1953 Local action of thyroxine on amphibian metamorphosis II. Development of the eyelids, nictiating membrane, cornea, and extrinsic ocular muscles in Rana pipens larvae effected by thyroxine cholesterol implants. J Exp Zool 122:41-52

2. Wilt FH 1959 The organ specific action of thyroxine in visual differentiation. J Embryol Exp Morphol 7:556-563

3. Munz FT, Swanson RT 1965 Thyroxine induced changes in the proportions of visual pigments. Am Zool 5:683-687

4. Rothstein H, Worgul BV, Briggs R, van Bushkirk R 1973 Triiodothyronine and thyroxine induction of mitosis in adult frogs. Experientia 29:1292-1295

5. Weinsieder A, Roberts L 1979 Effects of thyroid hormones on cell proliferation in the cornea and lens of hypophysectomized adult frogs. IRCS Med Sci 7:578

6. Masterson E, Edelhauser HF, Van Horn DL 1977 The role of thyroid hormone in the development of the chick corneal endothelium and epithelium. Invest Ophthalmol Vis Sci 16:105-115

7. Coulombre AJ, Coulombre JL 1964 Corneal development. III. The role of the thyroid in dehydration and development of transparency. Exp Eyes Res $3: 105-114$
8. Masterson E, Edelhauser HF, Van Horn DL 1975 Development of corneal transparency in embryonic chick. Influence of exogenous thyroxine and thiouracil on structure water and electrolyte content. Dev Biol 43:233-239

9. Langman J, Van Faassen F 1955 Congenital defects in the rat embryo. Am J Ophthalmol 40:65-76

10. Khamsi F, Eayrs JT 1966 A study of the effects of thyroid hormones on growth and development. Growth 30:143-150

11. Schapiro 1968 Some physiological, biochemical and behavioral consequences of neonatal hormone administration of cortisol and thyroxine. Gen Comp Endocrinol 10:214-228

12. Cohen S 1962 Isolation of a mouse submaxillary gland protein accelerating incisor eruption and eyelid opening in newborn animal. $\mathrm{J}$ Biol Chem 237:1555-1562

13. Frati L, Daniele S, Delogu A, Covelli I 1972 Selective binding of the epidermal growth factor and its specific effects on the epithelial cells of cornea. Exp Eye Res 14:135-141

14. Savage CR Jr, Cohen S 1973 Proliferation of corneal epithelium induced by epidermal growth factor. Exp Eye Res 15:361-366

15. Fabricant R, Salisbury JD, Berkowitz RA, Kaufman HE 1982 Regenerative effects of epidermal growth factor after penetrating keratoplasty in primates. Arch Ophthalmol 100:994-995

16. Gospodarowicz D, Mescher AL, Birdwell CR 1977 Stimulation of corneal endothelial cell proliferation in vitro by fibroblast and epidermal growth factors. Exp Eye Res 25:75-89

17. Gospodarowicz D, Mescher AL, Brown KD, Birdwell CR 1977 The role of fribroblast growth factor and epidermal growth factor in the proliferative response of the corneal and lens epithelium. Exp Eye Res 25:631-644

18. Hollenberg MD 1975 Receptors of insulin and epidermal growth factor relation to synthesis of DNA in cultured rabbit lens epithelium. Arch Biochem and Biophys 171:371-377

19. Reddan JR 1982 Control of cell division in the ocular lens, retina and vitreous humor. In: McDevitt DS (ed) Cell Biology of the Eye, Academic Press, New York, pp 299-375

20. Gospodarowicz D, Biolecki H, Thakral TK, The angiogenic activity of fibrobalst and epidermal growth factors. Exp Eye Res 28:501-504

21. Hamburgh M, Mendoza LA, Burkart JF, Weil F 1970 Thyroid dependent processes in the developing nervous system. In: Hamburgh $\mathbf{M}$, Barrington EJW (eds) Hormones in Development. Appleton-Century-Crofts, New York pp 403-415

22. Hoath SB, Lakshmanan J, Scott SM, Fisher DA 1983 Effect of thyroid hormones on epidermal growth factor concentration in neonatal mouse skin. Endocrinology 112:308-314

23. Lowry OH, Rosebrough NJ, Farr AL, Randall RJ 1951 Protein measurement with the Folin phenol reagent. J Biol Chem 193:263-275

24. Savage CR Jr, Cohen S 1972 Epidermal growth factor and a new derivative. Rapid isolation procedures and biological and chemical characterization. J Biol Chem 247:7609-7611

25. Hoath SB, Lakshmanan J, Koestner M, Fisher DA 1982 Differential effects of thyroid hormones on tissue epidermal growth factor concentrations during development. 55th Meeting American Thyroid Association T-89

26. Waggoner PR 1978 Effects of exogenous thyroxine on the surface morphology of the developing check anterior corneal epithelium. Experientia 34:12131215

27. Carpenter G 1978 The regulation of cell proliferation. Advances in the biology and mechanism of action of epidermal growth factor. J Invest Dermatol 71:283-287

30. Cohen S, Elliott GA 1963 The stimulation of epidermal keratinization by a protein isolated from the submaxillary gland of the mouse. J Invest Dermatol 40:1-5

31. Schonbrunn A, Krasnoff M, Westdendof JM, Tashjian H Jr 1980 Epidermal growth factor and thyrotropin releasing hormone act similarly on a clonal pituitary cell strain. J Cell Biol 85:786-797

32. Hirata Y, Orth DN 1979 Epidermal growth factor (urogastrone) in human tissues. J Clin Endocrinol Metab 48:667-672

33. Westermark K, Westermark B 1982 Mitogenic effect of epidermal growth factor on sheep thyroid cells in culture. Exp Cell Res 138:47-55

34. Cohen $S 1965$ Growth factors and morphogenic induction. In: M.D. Anderson Tumor Institute: Developmental and Metabolic Control Mechanisms and Neoplasia. Williams \& Wilkins Co. Baltimore, pp 252-272

35. Steidler NE, Reade PC 1980 Histomorphological effects of epidermal growth factor on skin and oral mucosa in neonatal mice. Arch Oral Biol 25:37-43

36. Heimberg M, Weinstein T, Lequire VS, Cohen S 1965 The induction of fatty liver in neonatal animals by a purified protein (EGF) from mouse submaxillary gland. Life Sci 4:1615-1633

37. Adamson ED, Rees AR 1981 Epidermal growth factor receptors. Molecular and cellular. Biochemistry 34:129-152

38. Adamson ED, Warshaw SB 1982 Down regulation of epidermal growth factor receptors in mouse embryo. Dev Biol 90:430-434

39. Covelli T, Rossi R, Mozzi R, Frati L 1972 Synthesis of bioactive ${ }^{131}$ I labeled epidermal growth factor and its distribution in rat tissues. Eur $\mathrm{J}$ Biochem 27:225-230

40. Byyny RL, Orth DN, Cohen S, Doyne ES 1974 Epidermal growth factor effects of androgens and adrenergic agents. Endocrinology 95:776-782

41. Nexo E, Hollenberg MD, Bing J 1982 Aggressive behavior in mice provokes a marked increase in both plasma epidermal growth factor and renin. Acta Physiol Scand 111:367-371 